\title{
Foreign Material on Business History Deposited in the Baker Library
}

From time to time during the life of the Society new fields of endeavor have been opened up, thus leading to a general broadening of the organization's activities. One such added activity that has assumed a position of importance is the collection of business historical material in foreign countries. In the six year period that the Society has been seeking foreign material there has been an influx into the Baker Library of hundreds of documents on business abroad.

While in Paris in the fall of 1928, Mr. Frank C. Ayres, executive secretary of the Society, learned from the American Consul that the cooperation of the diplomatic and consular service could probably be obtained in the search for historical data abroad. Immediately after returning to the United States Mr. Ayres communicated with the Department of State officials. He found that they were thoroughly cooperative and that they would circularize all foreign service officers asking that assistance be given the work of the Society. Following this general letter the Society sent a letter to the consular and diplomatic representatives asking for lists of foreigners who might assist in the project.

The response of the Foreign Service representatives was highly gratifying; for information on potential sources of business data poured in from all parts of the world. When these individuals and organizations outside the United States were approached, they responded with voluminous material on commerce and industry in other countries. Since the original efforts were made by the Society, this phase of its activity has been carried forward virtually through its own momentum. In essence it may be said that the Society has voluntary representatives in most of the important foreign countries, always on the alert for worthwhile material.

Some idea of the size of this foreign field may be gathered from a survey of the acquisitions from abroad in the last year. Within that period material has been received from forty-two countries in all corners of the earth. Finland, Holland, Germany, England, New Zealand, and Argentina have been the leading contributors. 
Of course it is impossible to secure manuscript material abroad, but the books and publications that are received will prove increasingly important to the business historian of the future.

Anniversary publications of foreign companies, annual reports of banks and industrial firms, government documents, and industrial photographs comprise the greater portion of these foreign acquisitions. The Society is grateful for the interest shown this phase of its work by government representatives and supporters in foreign lands, and hopes that they will continue to give their enthusiastic support.

\section{Secretary's Column}

Since the publication of the last Bulletin the Society has received and gratefully acknowledges the following acquisitions:

From Mr. D. F. Barber, Chandler \& Barber, Boston: nine issues of Hardware Retailer for 1933 and 1934 ; twenty-two miscellaneous catalogues of hardware appliances.

From Mr. Lee M. Friedman, Boston: twenty-seven account books; miscellaneous papers relating to receivership proceedings; correspondence; operating statements; voyage records; Federal tax returns; etc., of Crowell \& Thurlow Steamship Company, Boston, covering the period, approximately, from 1912 to 1933 .

From Mr. R. I. Robertson, John I. Brown \& Sons, Inc., Boston: eighteen issues of Hardware Retailer, 1933 and 1934.

From Burr, Gannett \& Company, Boston: a collection of miscellaneous business magazines, market letters, prospectuses, financial service bulletins, and other literature relating to current investments.

From Mr. Henry Plympton Harrington, Woburn, Massachusetts: a collection of miscellaneous books, transferred to Widener Library.

From Mr. Seth T. Gano, Boston: various maps, reports, photostat reproductions of drawings, coal trade publications, etc., which were used by James Donald and F. R. Wadleigh in I913 to compile for Gauley Coal Land Company a report on the possibilities of establishing an export trade.

From Miss Florence Bradley, Librarian, Metropolitan Life Insurance Company, New York City: Addresses Delivered at the Triennial Conventions and Managers' Annual Banquets of the Metropolitan Life Insurance Company, Vol. I, 1923, Vol. II, 1928.

From an officer of the Society: twenty-seven additional documents relating to the Boston Water Power Company, 1847-1861; Robert Murray Haig 